TAO, Vol. 11, No. 3, 701-708, September 2000

\title{
The 21 September, 1999 Chi-Chi Earthquake in Taiwan: Implications for Tsunami Earthquakes
}

\author{
Tetsuzo Seno ${ }^{1, *}$ \\ (Manuscript received 24 February 2000, in final form 29 May 2000)
}

\begin{abstract}
The 1999 Chi-Chi earthquake in Taiwan can be regarded as a subduction zone earthquake in a tectonic sense. It was associated with an abnormally uplifted area in the northwestern corner of the earthquake fault. The area is in the river bed where the Ta-Chia River runs from east to west. The large horizontal movement of the basement south of the river to the north could have produced the multiple thrusts and the abnormal uplifts amounting to 3-6 $\mathrm{m}$ due to the shortening of the accretionary prism.

These inelastic uplifts would imply an abnormal tsunami if the area were under the sea, thus suggesting a new factor for the mechanism of tsunami earthquakes, which is an uplift of the sediment or weak accretionary prism caused by a sudden horizontal movement on the décollement beneath the lowermost inner trench slope like sand being pushed up by a bulldozer. This is consistent with the features of tsunami earthquakes having the low dip angle thrust extending to the trench.
\end{abstract}

(Key words: Chi-Chi earthquake, Accretion, Sediment, Décollement, Tsunami earthquakes)

\section{INTRODUCTION}

The Westem foothills and west Central Range are composed of Tertiary rocks originally sedimented in the Eurasian continental margin (e.g., Ho 1986), but have become an accretionary prism due to the collision between the Luzon arc and the continent since the Pliocene (Suppe 1981; Chi et al. 1981). The accretionary prism is cut by a number of east-dipping thrusts (Suppe 1981, 1985). The surface faults of the 21 September, 1999 Chi-Chi earthquake are mostly elongated along the Chelungpu fault, which is a surface expression of one of the thrusts (Suppe 1985). When compared with the geologic cross-section (Suppe 1985), several factors indicate that earthquake faulting occurred at the thrust and also extended to the

\footnotetext{
${ }^{1}$ Earthquake Research Institute, University of Tokyo, Tokyo 113-0032, Japan

${ }^{\star}$ Corresponding author address: Prof. Tetsuzo Seno, Earthquake Research Institute, University of Tokyo, Tokyo 113-0032, Japan; E-mail: seno@eri.u-tokyo.ac.jp
} 
décollement.These factors include the mainshock epicenter (Central Weather Bureau), the Harvard CMT solution, the moment release as revealed by teleseismic body wave analysis (Kikuchi et al. 2000) and the aftershock distribution as determined by short-term observations, a cooperative venture by Taiwan and Japan (Hirata et al. 2000). However, it is true that aftershock activities showed greater complications, such as a further step-down into the deeper level of the décollement (see also Kao and Chen 2000, and Dahlen et al. 1984 which shows a geologic section with such step-downs).

Although Taiwan is in a collision zone, it is young (Chi et al. 1981) and is mostly made of the accretionary prism (Suppe 1981). Thus, if the island of Taiwan were covered by sea water, it would not differ much from a subduction zone. Because interplate thrust-type earthquakes at subduction zones generally occur at the thrust in an accretionary prism and at the décollement below it, the Chi-Chi earthquake can be regarded as an interplate earthquake in a subduction zone-much like the 1944 Tonankai and 1946 Nankai earthquakes in the Nankai Trough off southwestern Japan.

\section{ABNORMAL UPLIFTS}

The Chi-Chi event showed a number of peculiar phenomena which are not usually seen with inland intraplate earthquakes like the 1995 Kobe $\left(M_{s}=7.2\right)$ event. The surface ruptures left little damage except for the collapsing of buildings which stood just across the surface fault traces. The slip directions of the surface faults were mostly NW, consistent with the earthquake slip vector (Harvard CMT solution; Kikuchi et al. 2000), but there were also many W-SW and N directed slips (Otsuki and Yang 1999; Sugiyama et al. 2000). In the northwestern corner of the earthquake fault, significant uplifts at the surface ruptures occurred. These may all have been related to the fact that the earthquake fault cut the shallow portion of the accretionary prism; detailed descriptions and a discussion of these features will be given elsewhere (Seno et al. 2000). Here I focus on the last feature, namely the significant uplifts in the northwestern corner.

The bed of the Ta-Chia River is located in the northwestern corner and runs from east to west cutting the Western foothills, poring into the Coastal Plain (Fig. 1). In the river bed, the Chi-Chi event produced a fall, a gravel scarp in a peach farm, and destruction of a dam; the uplifts at these localities amounted to 6,6 and $9 \mathrm{~m}$, respectively (e.g., Otsuki and Yang 1999). In contrast, the uplifts of the basement to the south of the river bed measured by GPS were only $3 \mathrm{~m}$ (Yu et al. 1999).

The northwestern part of the earthquake fault had large seismic slips of up to $9 \mathrm{~m}$ (Kikuchi et al. 2000). GPS also showed that there was a large NNW horizontal movement of the basement just south of the river totaling $7 \mathrm{~m}$ (Yu et al. 1999). Adding $0.7 \mathrm{~m}$ of the SSE movement of the basement north of the river, there was a horizontal movement of $7.7 \mathrm{~m}$ between the basements. The surface faults in the northwestern corner also showed horizontal slips amounting to $7 \mathrm{~m}$ (Otsuki and Yang 1999). However, the large uplifts cited above could not have been due to the large slips of the earthquake fault in the northwestern part because the basement uplift of $3 \mathrm{~m}$ can be expected from the elastic rebound of the 6-m dip-slip (Kikuchi et al. 2000) 


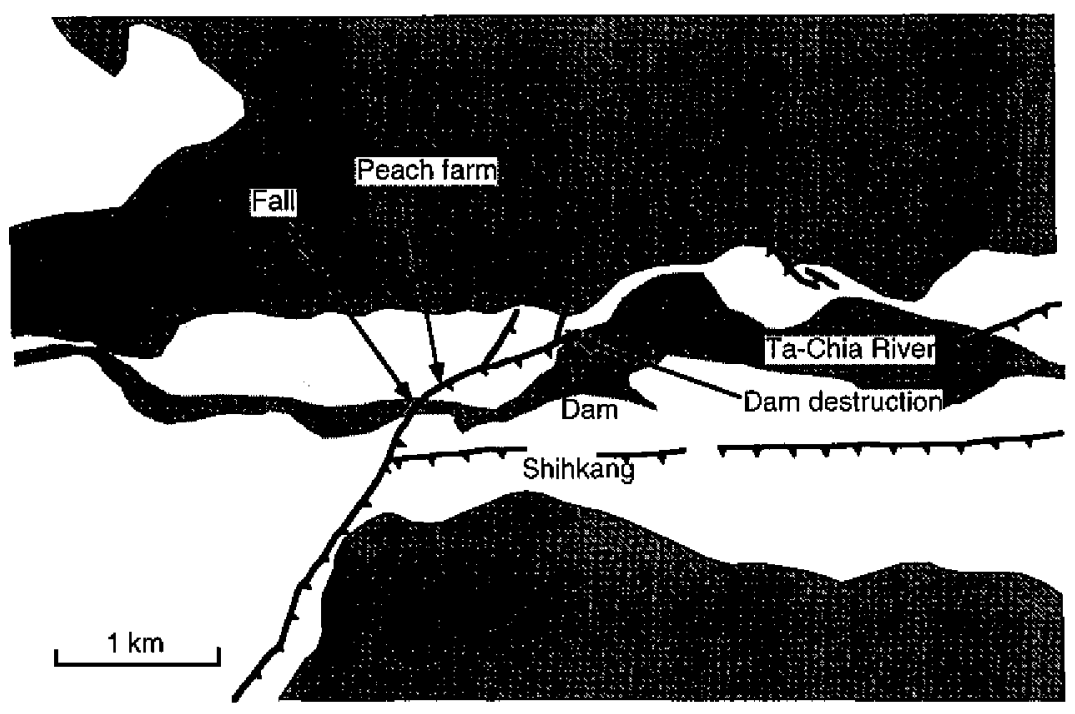

Fig. 1. Index map of the northernmost corner of the surface faults. The fault traces are from the Central Geological Survey. The basement made of the accretionary prism is shaded, and the sedimentary river bed is left blank. At the fall, the peach farm, and the dam destruction site, abnormal uplifts were observed.

on the fault plane dipping at 30 degrees. This means there is a 3-6 m difference between the elastic uplift and the observed ones, which implies that there were extra uplifts in the river bed.

The hanging wall in the river bed is composed of the Pliocene sandstone, and the sedimentary cover is thin (K. Otsuki personal communication 2000). Note also that multiple thrusts appeared in the northwestern comer (Fig. 1). Another thrust (i.e., the deformation front) appeared on the hill northwest of the site of the dam destruction (C.-N. Yang, personal communication 1999), though this is not shown in Fig. 1.

In this study I apply the sand box experiment over the ductile décollement (Koyi et al. 2000 ) to explain the additional uplift in the northwestern corner. Koyi et al. (2000) demonstrated that sand which shortened above a ductile substrate shows multiple thrusts with simultaneous displacements (Fig. 2b), while the sand above the frictional sheet shows a single thrust (Fig. 2a). There was a large northward component of faulting in the northwestern corner as seen from the GPS horizontal movement $\left(\mathrm{N} 20^{\circ} \mathrm{W}\right.$, Yu et al. 1999), indicative that the slip there was nearly horizontal. In addition, the shallowest portion of the earthquake fault in the same location is likely to have undergone very low friction, as seen from the high velocity of faulting recorded on the strong motion seismograms (Lee et al. 1999). Hence, the slip at the northwestern corner can be regarded as a slip on the ductile decollement, which could have then produced the multiple thrusts and the associated uplifts.

For the deformation shown in Fig. $2 b$, the average uplift of the area, $U_{Z}$, can be calculated by treating the mass above the décollement as plastic material. Then considering the 
mass balance yields

$$
\mathrm{U}_{\mathrm{z}}=\mathrm{dH} / \mathrm{W},
$$

where $\mathrm{H}$ and $\mathrm{W}$ are the thickness and width of the deformed prism, respectively, and $\mathrm{d}$ is the amount of the horizontal differential movement between the basements. W and $\mathrm{d}$ are around 1$2 \mathrm{~km}$ and $8 \mathrm{~m}$, respectively. This means that if $\mathrm{H}$ is around $0.5-1 \mathrm{~km}$, the uplifts of $3-6 \mathrm{~m}$ of the river bed can be explained. This value of $\mathrm{H}$ would be reasonable at the toe of the hanging wall.

\section{MECHANISM OF TSUNAMI EARTHQUAKES}

Since the uplifts of the northwestern corner were greater than expected from the elastic rebound theory, the uplifted area could have produced an abnormal tsunami if it were covered

(a)

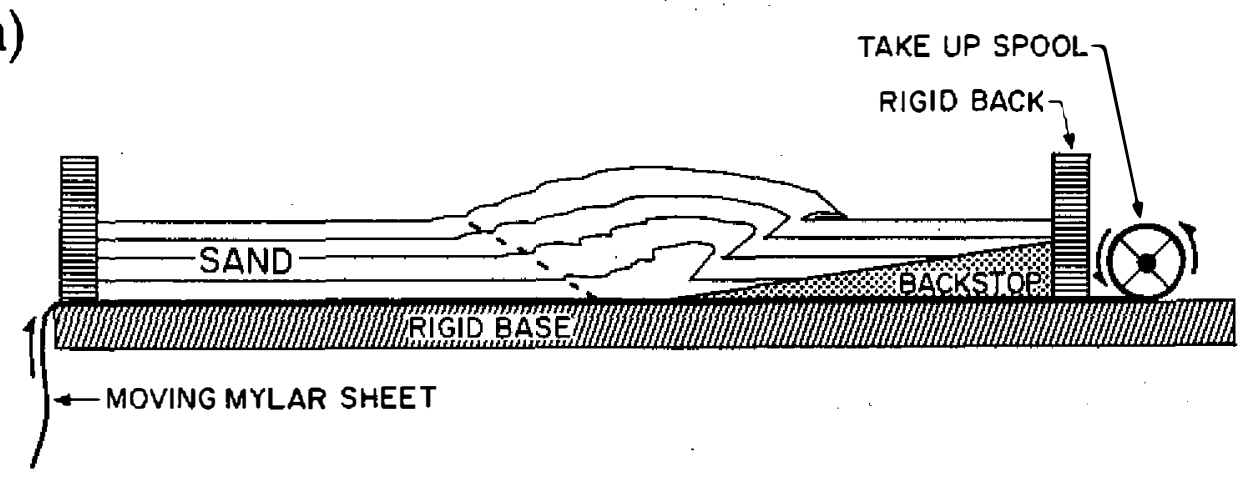

Fig. 2a. Schematic diagram of the laboratory sand box experiment by Byme et al. (1988). An underlying mylar sheet is pulled horizontally to the right beneath the originally flat-lying sand, simulating motion between the backstop and the sand along the plate interface. One thrust in the sand appears.

(b)

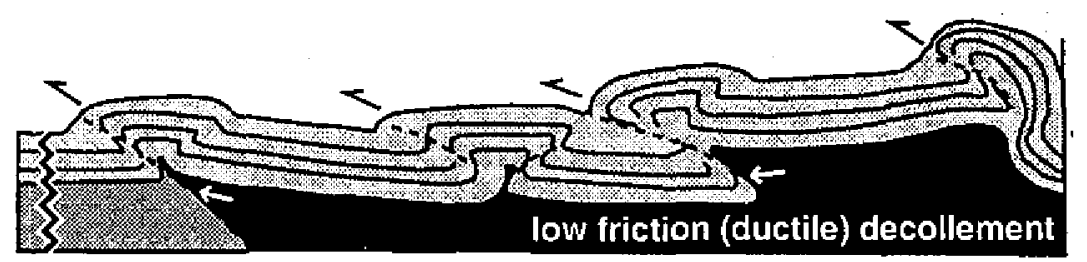

Fig. 2b. Sand box experiment simulating a slip on the ductile décollement (Koyi et al. 2000). Sand is put over the Newtonian silicone polymer. Multiple thrusts (half arrows) appear simultaneously. 
by sea water. "Abnormal" here means that the tsunami heights could have been larger than expected from the uplift of the ocean bottom due to the earthquake dislocation. The seismic slip in the northwestern corner had a time constant of about $10 \mathrm{sec}$ according to strong motion records (Lee et al. 1999); thus, the slip was certainly rapid enough to generate a tsunami.

Tsunami earthquakes are events which have unusually large tsunamis compared with their short-period seismic wave radiation. The abnormal uplifts in the case of the Chi-Chi earthquake, consequently, have implications for the mechanisms of tsunami earthquakes, although the Chi-Chi event itself might not be called a tsunami earthquake because of the limited extent of the area with abnormal uplifts.

The most prominent feature of tsunami earthquakes is the slow slip on the fault (Kanamori 1972); this reduces the surface wave magnitude measured at a 20 -second period compared with its total seismic moment, and is noted with many tsunami earthquakes, such as the 1896 Sanriku (Kanamori 1972), the 1963 and 1975 south Kuril (Fukao 1979; Pelayo and Wiens 1992), and the 1992 Nicaraguan (Ide et al. 1993; Kanamori and Kikuchi 1993) earthquakes. Nevertheless it has previously been pointed out that the seismic moment from the long period component is still not large enough to explain the observed large amplitudes of tsunamis (Fukao 1979; Imamura et al. 1993).

To shed light on this, Fukao (1979) proposed a mechanism by which faulting with a high dip angle within an accretionary prism causes an enhanced uplift. Furthermore, the low rigidity of the accretionary prism causes a larger slip with the same amount of seismic moment (See also Okal 1988). Recent seismological and tsunami-wave studies do not support this mechanism, however. The focal mechanisms of tsunami earthquakes generally have a very low dip angle, and their fault planes extend close to the trench axes (Pelayo and Wiens 1992; Satake 1994; Johnson and Satake 1997; Tanioka and Satake 1996). These factors suggest that the slip of tsunami earthquakes is on the décollement extending to the trench, rather than on the thrust branching from the décollement. Accordingly, the very low dip angle of the slip precludes a large amount of the basement upliftbecause the motion is nearly horizontal. The enhanced displacement due to low rigidity is not expected either since the stress drop must be very small at the toe of the accretionary prism (Byrne et al. 1988). Kanamori and Kikuchi (1993) pointed to additional mechanisms, such as land slides, for the 1896 Sanriku off northern Honshu and the 1946 Aleutian events.

In view of these earlier findings, it should be said that the cause of tsunami earthquakes has yet to be elucidated, although the slow slip constitutes one important factor. Here, based on the abnormal uplifts associated with the Chi-Chi earthquake, a new factor for the mechanism of tsunami earthquakes is suggested. That is the mechanically weak accretionary prism at the toe of the rench slope is uplifted by the horizontal displacement on the ductile décollement (Fig. 2b).

A different, yet similar, mechanism can be conceived; the unconsolidated sediment at the lowermost trench slope is scraped and pushed up by the backstop (consolidated accretionary prism) like a bulldozer scraping sand or snow in front of it (Fig. 2a). In this case, a formula similar to (1) holds for the amount of the uplift $U_{2}$, where $W$ is replaced by the width of the uplifted sedimentary wedge, and $\mathrm{H}$ by the height of the backstop.

Take the 1896 Sanriku $M_{S}=7.2$ tsunami earthquake off northern Honshu as an example 
of the latter case. Figure 3 shows a cross-section of the Japan Trench simplified from the seismic section along $40^{\circ} \mathrm{N}$ (von Heune 1986). $\mathrm{H}$ is estimated to be $4 \mathrm{~km}$, while $\mathrm{W}$ is around 8 $\mathrm{km}$ in this section. Then about $3 \mathrm{~m}$ of uplift of the sedimentary wedge (slump deposit) can be expected by a dislocation of $6 \mathrm{~m}$ at the décollement. By numerical simulations, Tanioka and Seno (2000) showed that this amount of uplift of the sediment, with the basement uplift due to the elastic rebound, could have successfully generated tsunamis associated with the 1896 Sanriku earthquake. Without the sediment uplift, a dislocation of $10 \mathrm{~m}$ would have been necessary to explain the observed tsunamis. The morphology of the Japan Trench is more or less imilar to that shown in Fig. 3 in the fault area of the 1896 event (Cadet et al. 1987).

\section{CONCLUSIONS}

From the perspective of tectonics, the 1999 Chi-Chi Taiwan earthquake is regarded as a subduction zone earthquake. It was associated with an abnormally uplifted area in the northwestern portion of the earthquake fault. The area is the river bed where the Ta-Chia River runs from east to west. The large horizontal movement of the basement south of the river to the north could have produced the abnormal uplifts amounting to $3-6 \mathrm{~m}$ due to the multiple thrusts on the ductile décollement. The uplifts could have produced an abnormal tsunami if the area were under the sea, which is suggestive of a mechanism for tsunami earthquakes. The mechanism proposed here is that a sudden horizontal movement at the décollement beneath the low-

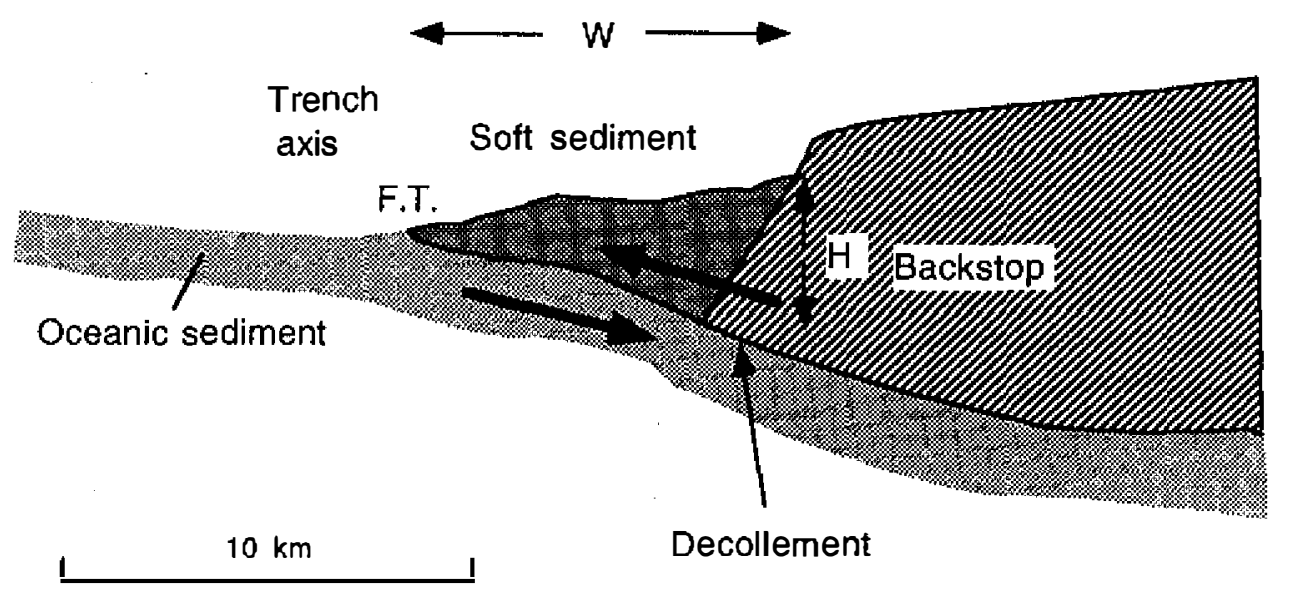

Fig. 3. Typical cross-section of the lower trench slope-trench wedge seen in the Japan Trench. This profile is constructed from the multi-channel seismic section ORI78-4 along about $40^{\circ} \mathrm{N}$ (von Huene 1986). The soft sediment (slump deposits) will be pushed toward the trench by a slip at the décollement at the time of a tsunami earthquake. $\mathrm{H}$ is the height of the backstop and W is the width the soft sediment. F.T. denotes the frontal thrust. 
ermost inner trench slope causes an uplift of the sediment or weak accretionary prism. This mechanism is consistent with the features of tsunami earthquakes as revealed in recent studies, though the slow slip constitutes an important factor with regard to tsunami earthquakes. Further numerical simulations of the tsunamis of previous tsunami earthquakes are warranted in order to test the proposed mechanism.

Acknowledgments I benefited from the field survey of the surface faults of the Chi-Chi event and discussions with Kenshiro Otsuki, Chao-NanYang, Yuan Wang and Wuu-Liang Huang. I also would like to express my thanks to two anonymous reviewers for their useful comments, and John Suppe for providing a few geologic cross-sections of central Taiwan, Yoshiko Yamanaka, Yoshio Fukao, YuichiroTanioka, Kenji Kanjo, and Katsuhiko Ishibashi for discussions as well as Honn Kao for preprints.

\section{REFERENCES}

Byrne, D. E., D. M. Davis, and L. R. Sykes, 1988: Loci and maximum size of thrust earthquakes and the mechanics of the shallow region of subduction zones. Tectonics, 7 , 833-857.

Cadet, J.-P., K. Kobayashi, J. Aubouin, J. Boulegue, C. Deplus, J. Dubois, R. Von Huene, L. Jolivet, T. Kanazawa, J. Kasahara, K. Koizumi, S. Lallemand, Y. Nakamura, G. Pautot, K. Suyehiro, S. Tani, H. Tokuyama, and T. Yamazaki, 1987: The Japan Trench and its juncture with the Kuril Trench: Cruise results of the Kaiko project, Leg 3. Earth Planet. Sci. Lett., 83, 267-284.

Chi, W-R., J. Namson, and J. Suppe, 1981: Stratigraphic record of plate interactions in the Coastal Range of eastern Taiwan. Mem. Geol. Soc. China, 4, 155-194.

Dahlen, F. A., Davis, D., and J. Suppe, 1984: Mechanics of fold-and-thrust belts and accretionary wedges: Cohesive Coulomb theory. J. Geophys. Res., 89, 10087-10101.

Davis, D., J. Suppe, and F. A. Dahlen, 1983: Mechanics of fold-and-thrust belts and accretionary wedges. J. Geophys. Res., 88, 1153-1172.

Fukao, Y., 1979: Tsunami earthquakes and subduction processes near deep-sea trenches. $J$. Geophys. Res., 84, 2303-2314.

Hirata, N., S. Sakai, Z.-S. Liaw, Y.-B. Tsai, and S.-B. Yu, 2000: Aftershock Observation of the 1999 Chi-Chi, Taiwan, Earthquake. Bull. Earthquake Res. Inst.. (in press)

Ho, C. S., 1986: A synthesis of the geologic evolution of Taiwan. Tectonophysics, 125, 1-16.

Ide, S., F. Imamura, Y. Yoshida, and K. Abe, 1993: Source characteristics of the Nicaraguan tsunami earthquake of September 2, 1992. Geophys. Res. Lett., 20, 863-866.

Imamura, F., N. Shuto, S. Ide, Y. Yoshida, and K. Abe, 1993: Estimate of the tsunami source of the 1992 Nicaraguan earthquake from tsunami data. Geophys. Res. Lett., 20, 15151518.

Johnson, J. M., and K. Satake, 1997: Estimation of seismic moment and slip distribution of the April 1, 1946, Aleutian tsunami earthquake. J. Geophys. Res., 102, 11765-11774.

Kanamori, H., 1972: Mechanism of tsunami earthquakes. Phys. Earth Planet. Inter., 6, 346359. 
Kanamori, H., and M. Kikuchi, 1993: The 1992 Nicaragua earthquake: a slow tsunami earthquake associated with subducted sediments. Nature, 361, 714-716.

Kao, H., and W.-P. Chen, 2000: The Chi-Chi earthquake sequence: Active, out-of-sequence thrust faulting in Taiwan. Science, 288, 2346-2349.

Kikuchi, M., Y. Yagi, and Y. Yamanaka, 2000: Source process of the Sept. 211999 central Taiwan earthquake. Bull. Earthquake Res. Inst., Univ. of Tokyo. (in press)

Koyi, H. A., K. Hessami, and A. Teixell, 2000: Epicenter distribution and magnitude of earthquakes in fold-thrust belts: insights from sandbox models. Geophys. Res. Lett., 27, 273-276.

Lee, W. H. K., T. C. Shin, K. W. Kuo, and K. C. Chen, 1999: CWB Free-Field Storng-Motion Data from the 921 Chi-Chi Earthquake: Volume 1. Digital Acceleration Files on CDROM. Seismology Center, Central Weather Beureau, Taipei, Taiwan.

Okal, E., 1988: Seismic parameters controlling far-field tsunami amplitudes: A review. Natural Hazards, 1, 67-96.

Otsuki, K., and C.-N. Yang, 1999: Surface displacements of the faults associated with the 1999 Chi-Chi earthquake, Rep. Grant-in-Aid for Scientific Research for the Taiwan earthquake, 21 Sept., 1999 (in Japanese).

Pelayo, A. M., and D. A. Wiens, 1992: Tsunami earthquakes: Slow thrust-faulting events in the accretionary wedge. J. Geophys. Res., 97, 15321-15337.

Satake, K., 1994: Mechanism of the 1992 Nicaragua tsunami earthquake. Geophys. Res. Lett., 21, 2519-2522.

Seno, T., K. Otsuki, and C.-N. Yang, 2000: The 1999 Chi-Chi Taiwan earthquake: A subduction zone earthquake on land. Bull. Earthquake Res. Inst, Univ. of Tokyo. (in press)

Sugiyama, Y., A. Kariya, and T. Azuma, 2000: Surveys of the surface displacements of the faults associated with the Sept. 21, 1999 Chi-Chi earthquake. Rep. Corrd. Comm. Earthquake Prediction, in press (in Japanese).

Suppe, J., 1981: Mechanics of mountain building and metamorphism in Taiwan. Mem. Geol. Soc. China, 4, 67-89.

Suppe, J., 1985: Principles of Structural Geology. Prentice-Hall Inc., N. J., 537pp.

Tanioka, Y., and K. Satake, 1996: Fault parameters of the 1896 Sanriku tsunami earthquake estimated from tsunami numerical modeling. Geophys. Res. Lett., 23, 1549-1552.

Tanioka, Y., and T. Seno, 2000: The sediment deformation model for the 1896 Sanriku tsunami earthquake. Abstr. WPGM, 2000, Tokyo.

von Huene, R., 1986: To accrete or not accrete, that is the question. Geol. Rundsch., 75, 1-15. Yu, S.-B., L. C. Kuo, Y. J. Hsu, C. S. Hou, C. C. Liu, H. H. Su, J. F. Lee, and T. C. Lai, 1999: Coseismic and postseismic deformations associated with the 1999 Chi-Chi earthquake, Natural Sciences Newsletter, NSC., 11, 156-161. 